\title{
Development of Eco-friendly Aquaculture Design for Lobster Cultivation in Indonesia
}

Yeyes Mulyadi, Kriyo Sambodho, Nur Syahroni, Muhammad Zikra and Winda Amalia Herdianti*

Faculty of Marine Technology, Department of Ocean Engineering, Institut Teknologi Sepuluh Nopember, Kampus ITS, Keputih - Sukolilo, Surabaya, Indonesia

\begin{abstract}
Lobster products are important for the economy in fishing community. Climate change will lead a threat to lobster productivity. Therefore, a solution offered is to cultivate certain lobsters, especially those with high economic value by using Aquaculture. This research aims to develop a small-scale aquaculture for the cultivation of lobsters with bamboo as primary material, which is environmentally friendly and inexpensive. The proposed design of lobster aquaculture in this research adapt lobster habitat in its nature. Therefore, it uses the artificial reef as a shelter for lobster. The main structure of the lobster cage uses bamboo and the floater use HDPE (High-density polyethylene) barrels. The result of aquaculture motion analysis using numerical model has been validated by experimental test in Flume Tank. The differences result of heave RAO (Response Amplitude Operator) motion between numerical model and experimental test is $0.05 \mathrm{~m}$. The results of this validation analysis show that it is reasonable agreement.
\end{abstract}

Keywords: Lobster; Aquaculture; Bamboo; Mooring

\section{Introduction}

The Lobster product comes from two main models of production: wild lobster (marine and freshwater) catching and aquaculture cultivation harvesting. At the moment, lobster products are important in the global economy and food security.

Currently, the farming of lobsters in cages in Indonesia has good potential to develop using small-scale farming units, where many coastal lagoons can support the variety of cage designs used. The lobster aquaculture has been developed in Indonesia but there are some problems with still high cannibalism during the puerulus phase of lobster. In the future, the challenging of lobster cage design is to develop lobster cage that able to decrease number of cannibalism in lobster cultivation. Besides, selection of the farming of lobster location must be quite far from the shipping lanes and other structure in ocean. For example, lobster farming cannot be installed in the Madura Strait because Madura Strait is one of the busiest shipping lanes in Indonesia and many subsea pipelines have been installed in there [1].

Total lobster production in 2008, aquaculture supplied 3\%; however by 2009 aquaculture supplied over $5 \%$. The lobster production in Indonesia is dominated by catching lobster from ocean. To control the catching of lobster in the Indonesia Ocean, the Ministry of Marine Affairs and Fisheries has established new minimum size limits for lobsters by catching method (Permen KP2/2015, which reinforced the 1980 Presidential Decree) [2].

Indonesia's statistics in 2012 reveal that lobsters rank fourth among the highest export of crustacean commodities after Paneus Shrimp, Metapenaeus and Macrobrachium family. Based on FAO data in 2005, the lobster demand in Japan has been increased annually since 1980 [3].

Increasing market demand, both domestic and internationally, has encouraged lobster catching to increase. This will potentially endanger the sustainability of the lobster resources in Indonesia if not managed properly. With the transition to green economy, the lobster production must be managed through environmentally friendly production and more sustainable processing methods. It is therefore important to raise awareness and incentives for economic executants to be sustainable.

One of the efforts to maintain sustainability of the lobster production is performed by cultivating lobster using cage or commonly called aquaculture. Development can be very profitable especially if it is operated by traditional fishermen who live in coastal areas.

This research is to propose lobster aquaculture with adapting lobster habitat in its nature. The lobster which is selected and developed in this research is Panulirus longipes, Panulirus homarus and Panulirus ornatus. These lobsters only live in waters with the surface of current velocities between $20-40 \mathrm{~cm} / \mathrm{sec}$. This indicates that those lobsters are live in calm water areas which are suitable for bamboo, because it has buoyancy to float on water naturally.

\section{Materials and Methods}

The main structure of aquaculture is made of bamboo and tied with rope. This main structure will withstand all forces in lobster aquaculture. The bamboo will have two functions in the main structure, as the pathway and the base or foundation. The pathway structure uses some bamboos with a length of 6 meters, while floater uses HDPE barrels currently available in the market. The illustration of the concept cage design is presented as following in the Figures 1 and 2 .

\section{Data collection}

The data required to design Aquaculture structure are environmental data and material of lobster aquaculture.

\section{Environmental data}

In this research, the environmental data to develop the lobster cage uses wave data as presented in Table 1 . Table 1 describes about the environmental data in the planned location.

In this research, the kind of bamboo used is Apus bamboo. Apus

*Corresponding author: Winda Amalia Herdianti, Faculty of Marine Technology Department of Ocean Engineering, Institut Teknologi Sepuluh Nopember, Kampus ITS, Keputih - Sukolilo, Surabaya, Indonesia, Tel: 62315994251; E-mail: windaherdianti@gmail.com

Received January 24, 2018; Accepted April 12, 2018; Published April 16, 2018

Citation: Mulyadi Y, Sambodho K, Syahroni N, Zikra M, Herdianti WA (2018) Development of Eco-friendly Aquaculture Design for Lobster Cultivation in Indonesia. J Aquac Res Development 9: 527. doi: 10.4172/2155-9546.1000527

Copyright: ( 2018 Mulyadi Y, et al. This is an open-access article distributed unde the terms of the Creative Commons Attribution License, which permits unrestricted use, distribution, and reproduction in any medium, provided the original author and source are credited. 


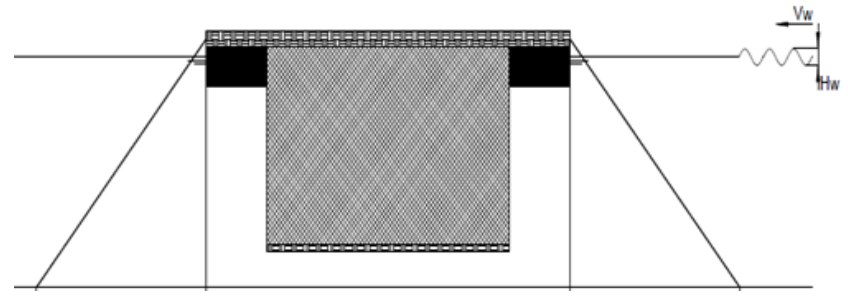

Figure 1: Concept of proposed aquaculture design.

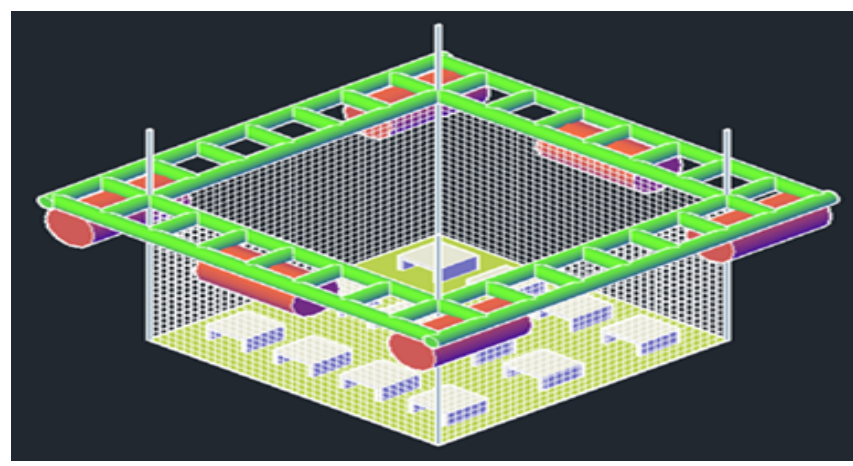

Figure 2: Model aquaculture state of free floating.

\begin{tabular}{|c|c|c|}
\hline Items & Values & Unit \\
\hline Water depth & 6 & Meter \\
\hline Wave significant height (50 years) & 2.35 & Meter \\
\hline Wave periode & 6.67 & Second \\
\hline Current velocity & 1 & Meter/sec \\
\hline
\end{tabular}

Table 1: Environmental data.

\begin{tabular}{|c|c|}
\hline Mechanical properties & MPa \\
\hline Tensile Strength & 150 \\
\hline Yield Strength & 53.53 \\
\hline Modulus of elasticity & 9901.96 \\
\hline
\end{tabular}

Table 2: Mechanical properties of apus bamboo.

Bamboo are often used in marine areas especially the seas because it strong against marine environmental and quite hard. Because of this characteristic, lobster could not destroy this material. Bamboo can live up to $1000 \mathrm{~m}$ above sea level. The stem can reach a height of 8 to 11 meters with a length of 45 to $65 \mathrm{~cm}, 5$ to $8 \mathrm{~cm}$ in diameter and 13 to 15 mm wall thickness.

Table 2 is described about mechanical properties of Apus bamboo. Mechanical properties consist of tensile strength, yield strength and modulus of elasticity. Tensile strength is maximum load that a material can support without fracture when being stretched. Yield strength is maximum stress that can be developed in a material without causing deformation. Modulus of elasticity is the ratio of the stress in material to the resulting strain within the elastic limit. Table 3 describes about the physical properties of bamboo Apus. The properties consist of water content and density.

\section{Methodology}

This research has aim to develop aquaculture design for lobster cultivation in calm water area in Indonesia. The main structure is by using the Apus bamboo because of the economical reason and its strength. The structure motion analysis is using numerical modelling method. The validation of numerical modelling is performing by simple experimental test in Flume Tank. The flowchart of methodology is shown in Figure 3. The first step in this research is collected environmental and deterministic data. After that, it started the design process. The proposed design is illustrated in the numerical model and prototype. After the RAO result obtained by numerical model, it have to validated by comparing the numerical model result with experimental result. If the comparison result less than $0.1 \mathrm{~m}$, then the proposed design could be accepted.

\section{Theory}

\section{Lobster}

Lobsters have a high protein that lives behind the rocks in calm waters such as in the bays, islands, beaches and sheltered areas, especially in areas where pey bottom and seaweed are overgrown. They do not like open spaces, wavy, strong, and muddy. Lobsters generally inhabit shallow waters that have a depth between 10-15 meters, but at certain moments, lobsters move to a deeper place. Lobsters include aquatic animals that are omnivorous, whether plant or animal that is alive or dead. The feed consists of small shrimp, fish, worms, soft animals and the rest of aquatic animals that have died. Lobsters use their nails or claws to hold the masses, then put into the mouth [4].

\section{Design criteria}

The design of optimum aquaculture design is done by iteration process (calculation, analysis, etc.) from layout, shape, dimension and material, and investment cost. There are several main criteria in designing aquaculture as follows $[5,6]$ :

\begin{tabular}{|c|c|c|}
\hline \multirow{2}{*}{ Condition } & \multicolumn{2}{|c|}{ Physical Properties } \\
\cline { 2 - 3 } & wc (\%) & $\mathrm{P}\left(\mathrm{g} / \mathrm{cm}^{3}\right)$ \\
\hline Regular & 19.11 & 0.69 \\
\hline Dry plants & & 0.58 \\
\hline
\end{tabular}

Table 3: Physical properties of bamboo apus.

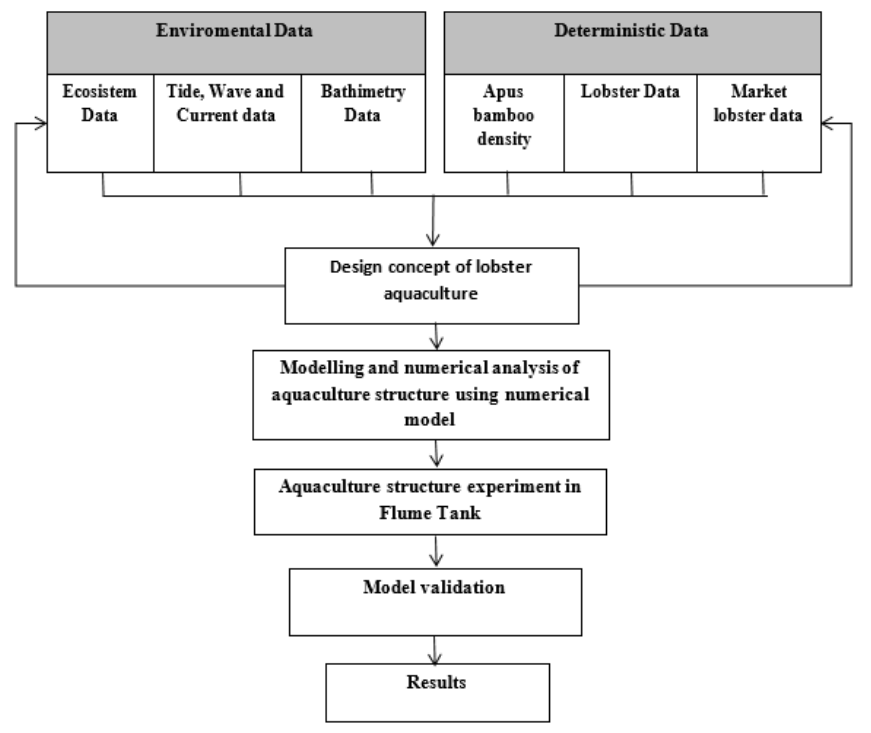

Figure 3: Methodology flow chart. 
1. The aquaculture structure must be able to resist forces from the marine environment.

2. The net should be able to withstand wastage due to environmental load (volume reduction is kept to a minimum).

3. Must be able to accommodate the number of animals that have been determined.

4. Must be easy for fabrication, installation, and maintenance.

\section{The six degree of freedom couple movement}

The floating building to be reviewed consists of six degrees of freedom, assuming that the oscillation movements are linear and harmonic, and the coupling differential equations can be written as follows [7]:

$\sum_{n=1}^{6}\left[\left(M_{j k}+A_{k}\right) \xi_{k}+B_{k} \xi_{k}+C_{k} \xi_{k}\right]=F_{j} e^{i w t}, j=1$

$\mathrm{M}_{\mathrm{j}} \mathrm{k}=$ Component of ship mass matrix.

$\mathrm{A}_{\mathrm{j}} \mathrm{k}, \mathrm{B}_{\mathrm{j}} \mathrm{k}=$ Matrix of added mass coefficient and attenuation.

$\mathrm{C}_{\mathrm{j}} \mathrm{k}=$ Returning hydrostatic force coefficients.

$\mathrm{F}_{j}=$ Amplitude of excitation force in complex quantities.

\section{Structural modeling}

F1, F2, and F3 are the amplitude of excitation forces which result in surge, sway, and heave, while F4, F5, and F6 are the amplitude of excitation moments for roll, pitch, and yaw.

\section{Structure responses}

Response Amplitude Operator (RAO) or also called the transfer function is a dynamic movement response function of the structure that occurs due to waves in a certain frequency range. RAO is a tool to transfer wave force into dynamic movement response structure [8-19].

Response of the structure motion analysis is performed to analyze a response amplitude operator (RAO) of the structure cage.

The RAO formulation is shown in Equation 2:

$\mathrm{SR}=[\mathrm{RAO}(\omega)]^{2} \mathrm{~S}(\omega)$

where,

$\mathrm{SR}=$ Spectrum response $\left(\mathrm{m}^{2}-\mathrm{sec}\right)$

$\mathrm{S}=$ Wave spectrum $\left(\mathrm{m}^{2}-\mathrm{sec}\right)$

$\mathrm{RAO}=$ Transfer function

\section{Mooring design}

In this mooring design uses 4 catenary mooring. The catenary mooring is placed at the corner between floater and the pathway meanwhile, for the rope in this mooring uses the wire rope. The catenary mooring system is the most common mooring system. It is hanging horizontally at the seabed. Pile on the sea bed is considered to be strong, so that later on the calculation is focused on the rope tension.

The strength of the mooring system is analyzed by checking the tension responses for each mooring rope. Tension on the mooring rope should be in accordance with the safety factor criteria. Safety factor for mooring line must be greater than 12 .

Safety factor equation is shown in Equation 3:

$$
S F=\frac{\text { Minimum Breaking Load }}{\text { Maximum Tension }}
$$

\section{Design and modelling}

Preliminary design and buoyancy design from vertical loads.

\section{Analysis of main structure}

Main structures of the cage consist of pathway and floater. The pathway is made from several bamboo combinations. The bamboo structure consists of outer frame, inner frame and stiffener. The bamboo density is $0.69 \mathrm{~g} / \mathrm{cm}^{3}$ for each bamboo.

The floater is made to maintain the cage remain afloat despite being given a heavy load. The floater is made of 200 liters HDPE barrel and each barrel has outer diameter of $58 \mathrm{~cm}$. High-density polyethylene (HDPE) or polyethylene high-density (PEHD) is a polyethylene thermoplastic that known for its strength to density ratio and has stronger intermolecular forces and tensile strength. In this research uses HDPE as a floater material because HDPE is light, inexpensive and strong against the influence of the marine environment

\section{Lobster}

This research planned to cultivate 300 lobsters inside the structure. Panulirus longipes, Panulirus homarus and Panulirus ornatus can be harvested when it weights \pm 400 grams. Thus, this cage is designed to could harvest $120 \mathrm{~kg}$ or 0.12 tons of all lobster.

\section{Artificial reefs}

Artificial reefs uses as a shelter for lobsters while changing skin and to protect the lobsters when in the puerulus phase. The artificial coral reefs are made from concrete with dimensions of $40 \mathrm{~cm} \times 40 \mathrm{~cm}$ $\times 20 \mathrm{~cm}$. The concrete weight is $\pm 5 \mathrm{~kg}$. In this proposed cage design is installed \pm 12 units of artificial reefs and tied on the woven bamboo floor to make it stay balanced.

\section{Live load}

The proposed lobster cage is designed to withstand live load from some activities of fisherman while perform some activities such as giving feed, maintenance, and harvesting. The live load is up to $300 \mathrm{~kg}$ or \pm 5 persons.

\section{Nets and floor}

Net uses to keep lobster inside the lobster cage structure and to protect lobsters from outside interference. The net has dimension $3 \mathrm{~m}$ of length, $3 \mathrm{~m}$ of width, and $2 \mathrm{~m}$ of depth with a $0.75 \sim 1$ " width of mesh net.

The floor is made of bamboo woven with a size of length of $3 \mathrm{~m}$ and width of $3 \mathrm{~m}$. The Floor has many functions; those are to maintain the shape of the nets, to place the artificial corals reef, and to prevent the leftover feed of the lobster to fall on the seabed, so it could reduce seabed pollution. Regularly, this floor will be lifted up for cleaning process.

\section{Total weight}

The total weight of the all structures and the equipment (net, floor and artificial reef, etc.) are $750 \mathrm{~kg}$. The Figure 4 below is the full picture of lobster aquaculture in this research excluding mooring. 


\section{Result and Discussion}

\section{Structure responses}

Lobster cage moored is a floating structure that has motion respond to wind, waves and current. The motion response analysis can be performed using analysis of Response Amplitude Operators (RAO). In this research, the RAO of the cage is calculated using numerical modeling. Motion analysis in the numerical modelling is assumed that the lobster cage is well moored, total weight $750 \mathrm{~kg}$, and environment load use data from Table 1. Figures 5-12 below show the RAO results from numerical modelling. The result of numerical analysis shows that maximum surge motion is $2.2 \mathrm{~m}$, RAO heave motion is $0.3 \mathrm{~m}$ and maximum pitch motion is 0.90 .

From the RAO's result, it could determine the rope size for the lobster cage. The rope selected is wire rope with diameter of $25.4 \mathrm{~mm}$ or 1 inch, weights $2.75 \mathrm{~kg} / \mathrm{m}$ with a stiffness of $29.8 \mathrm{MN}$. This rope can be able to withstand maximum tension of $399 \mathrm{KN}$. On the rope is also added sinker to keep the rope stay when the tide is low. The sinker has the weight is $40 \mathrm{~kg}$.

\section{Validation of modelling}

Validation of modelling is performed by comparison between numerical model and prototype experiment in Flume Tank at Department of Ocean Engineering ITS. The experiment model has 1:4.5 scales. The experiment has aim to determine characteristics of heave motion responses of aquaculture structure. The rolling and surge motion is couldn't have been performed in this experiment because of limited instrument in the flume tank. Experiments conducted by testing the prototype with wave period variation as presented in Tables 4 and 5 .

Measurement is conducted by measuring deck elevation changes to the reference point to get the heave motion of aquaculture prototype. The experimental result in this research is obtained that the biggest RAO of the heave motion is $0.35 \mathrm{~m}$. The experimental result in the flume tank is compared with the numerical analysis results for the validation process. There is a $0.05 \mathrm{~m}$ difference of the RAO heave motion between experimental result and numerical modelling analysis result. But, these differences still could be tolerated. The comparison between both results shows the same trend line. The following graph is RAO comparison of aquaculture motion analysis using numerical modelling and experiments on flume tank (Figure 9):

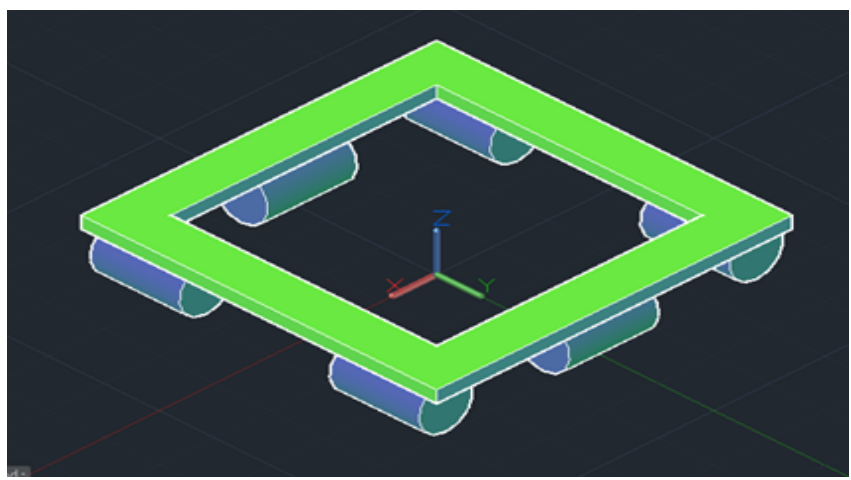

Figure 4: Pathway design.

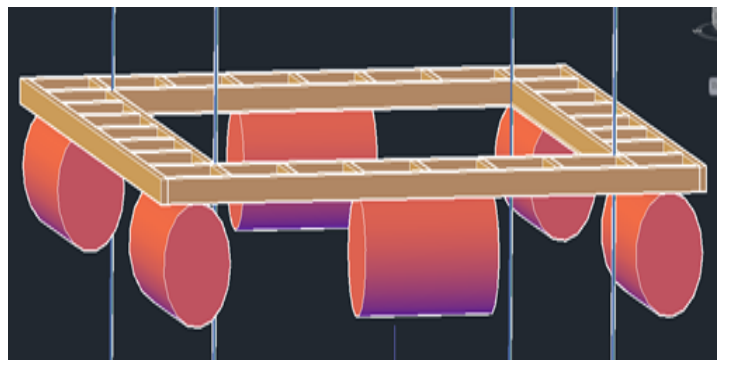

Figure 5: Floater design.

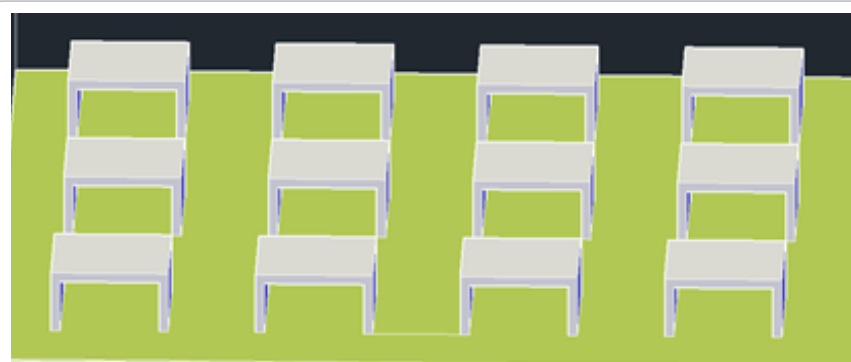

Figure 6: Artificial coral reef design.

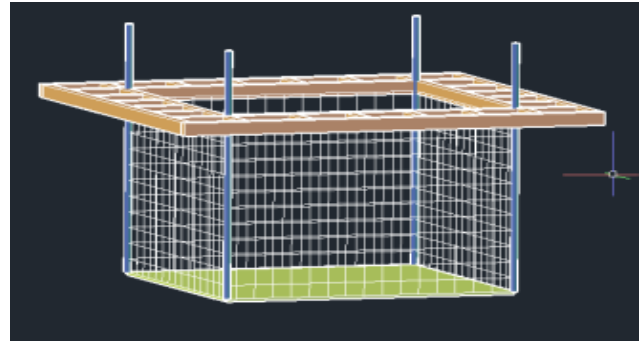

Figure 7: Nets and floor design.

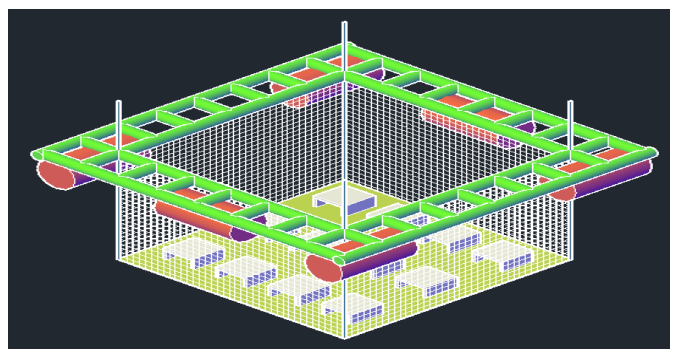

Figure 8: Aquaculture design (Exclude mooring).

RAO Result

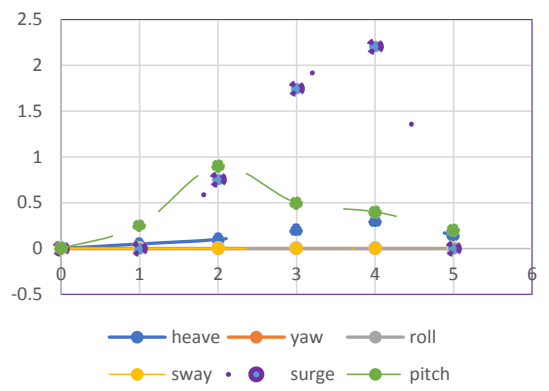

Figure 9: RAO result. 


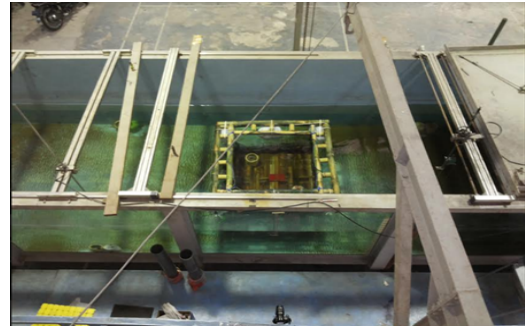

Figure 10: Flume tank

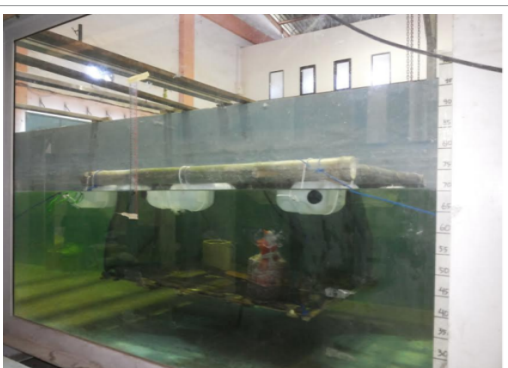

Figure 11: Side view of experiment.

Heave RAO Validation

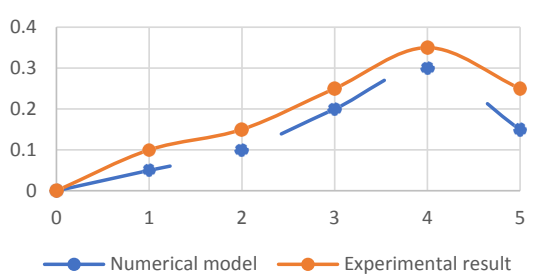

Figure 12: Model validation.

\begin{tabular}{|c|c|c|c|c|c|}
\hline Desc & Material & $\mathbf{L}(\mathbf{m})$ & $\mathbf{W}(\mathbf{m})$ & $\mathbf{D}(\mathbf{m})$ & $\mathbf{O D}(\mathbf{m})$ \\
\hline Outer Frame & Bamboo & 4 & 4 & -- & 0,15 \\
\hline Inner Frame & Bamboo & 3 & 3 & -- & 0,15 \\
\hline Stiffener & Bamboo & 0.5 & -- & -- & 0,15 \\
\hline Floater & Barrel 200 It & 0.9 & -- & -- & 0,58 \\
\hline Net & -- & 3 & 3 & 2 & -- \\
\hline
\end{tabular}

Table 4: Main data of the structure.

\begin{tabular}{|c|c|}
\hline $\mathbf{H}(\mathbf{m m})$ & $\mathbf{T}(\mathbf{s})$ \\
\hline 53.33 & 0.53 \\
\hline 53.33 & 1.33 \\
\hline 53.33 & 2.67 \\
\hline 53.33 & 4.00 \\
\hline 53.33 & 5.33 \\
\hline
\end{tabular}

Table 5: Variation of wave period in this research.

\section{Conclusions}

The conclusion of the aquaculture design study is presented as following points:

1. This study proposes the design of aquaculture with the size of 4.5 $\mathrm{m} \times 4.5 \mathrm{~m}$ and the depth of the net is only 2 meters. It makes the force at the structure is quite small. The structure of bamboo has sufficient strength when used for aquaculture for lobster cultivation.
2. Concept design of lobster aquaculture in this research adapt lobster habitat in its nature. Therefore, it uses some artificial reefs as a shelter for lobster while changing skin and avoids cannibalism during the puerulus phase of lobster

3. Main structure of the lobster aquacultures are the pathway and floater. The pathway uses several bamboo combinations consisted of outer frame, inner frame and stiffener. The floater uses 6 of HDPE barrel that has size for each HDPE barrel are diameter $58 \mathrm{~cm}$ and length $0.9 \mathrm{~m}$.

4. For mooring in this aquaculture uses catenary mooring system by wire rope. The selected size of rope is $25.4 \mathrm{~mm}$ of diameter and given a sinker with $40 \mathrm{~kg}$ of weight to keep the rope stay when the tide is low.

5. The validation of numerical modeling of aquaculture structure is performed by comparing experimental model in Flume Tank. There is a $0.05 \mathrm{~m}$ difference from numerical model analysis and experimental result, but it still could be tolerated.

\section{References}

1. Mulyadi $Y$ (2007) Design of grouper offshore farming in Indonesian waters Prosiding Seminar Nasional Teori dan Aplikasi Teknologi Kelautan. 2: 63-74.

2. Mulyadi Y, Kobayashi E, Wakabayashi N, Pitana T, Wahyudi P (2013) Development of ship sinking model over subsea pipeline for madura strait using AIS data, WMU J Maritime Affairs 13: 43-59.

3. California Enviromental Associates (2015) Indonesia fisheries 2015 review report. The David and Lucile Packard Foundation, California, USA.

4. FAO (2005) Review of the state of the world marine fishery resources, FAO Fisheries Technical Paper 457. FAO, Rome.

5. Rashid S, William WL, Cheung WY, Lam D, Samuel H (2011) Climate change impacts on the biophysics and economics of world fisheries. Nature Climate Change 1: 449-456.

6. Zikra S (2016) Design and modelling fender system or condensate and sulphuric acid jetty at senoro field, Central Sulawesi. ARPN J Eng Appl Sci 11: 896-900.

7. Aarsnes JV, Rudi H, Løland G (1990) Current force on cage, net deflection. J Eng Offshore Fish Farming. Thomas Telford, London, UK.

8. Lader F, Fredheim A (2006) Dynamic properties of a flexible net sheet in waves and current - A numerical approach. J Aquaculture Eng 2: 1.

9. Bhattacaryya R (1978) Dynamic of marine vehicles. John Wiley \& Sons, NY, USA.

10. Chakrabarti SK (1987) Hydrodynamis of offshore structure. Computational mechanic publication. Southampton, Boston, UK.

11. Djatmiko E (2012) Behavior and operability of sea buildings above random waves. Surabaya, Java, Indonesia.

12. American Petroleum Institute (1996) Recommended practice for designing and analysis of station keeping system for floating structures. Recommended Practice papers.

13. Bayu P, Clive J, Scott S (2011) Review of spiny lobster aquaculture in Indonesia, The $9^{\text {th }}$ International Conference and Workshop on Lobster Biology and Management. Bergen. Norway.

14. Karningsih K (2017) Nearshore aquaculture: Keramba jaring apung (kja) manajemen usaha and strategi pemasaran. Pusat Studi Kelautan: LPPMITSm, Surabaya, Indonesia.

15. Muhibburrahman N (2009) Design of construction and floating system on floating cage made FRP. Surabaya, Java, Indonesia.

16. Rahmazudi K (2014) Behavior bending structure bamboo frame using connection bolts and ropes ljuk-Bogor. Bogor Agricultural University, Indonesia.

17. Sutomo J (1999) Handout of hydrodynamics II. FTK - ITS, Surabaya, Indonesia

18. Suyuthi A (2006) Dynamic stability of offshore keramba type self-tensioning structure. Journal Teknologi Kelautan 10: 40.

19. Tim P (2015) Perikanan lobster laut, Report from Indonesia WWF-Indonesia ( $1^{\text {st }}$ edn). Jakarta, Indonesia. 